The Version of Record of this manuscript has been published and is available in Resources Conservation and Recycling, Volume 78, September 2013, pp. 124-135.

Published: September 2013

DOI: http://dx.doi.org/10.1016/j.resconrec.2013.07.008

\title{
An Update on Inter-Country Differences in Recovery and Utilization of Recycled Paper
}

\author{
Heli Arminen*a, Maija Hujalaa, Kaisu Puumalainen ${ }^{a}$, Anni Tuppuraa, Anne Toppinen ${ }^{b}$ \\ aSchool of Business, Lappeenranta University of Technology, P.O. Box 20, Fl-53851 Lappeenranta, Finland \\ ${ }^{b}$ Department of Forest Sciences, University of Helsinki, P.O. Box 27, FI-00014 University of Helsinki, Finland \\ *Corresponding author. Tel.: +358 408336756 . \\ E-mail addresses: heli.arminen@lut.fi (H.Arminen), maija.hujala@lut.fi (M. Hujala), kaisu.puumalainen@lut.fi \\ (K. Puumalainen), anni.tuppura@lut.fi (A.Tuppura), anne.toppinen@ @elsinki.fi (A. Toppinen)
}

\begin{abstract}
The use of recovered paper as raw material in the paper and board industry has increased heavily during recent decades. At the same time, growing environmental awareness has raised the interest in recycling and a more sustainable way of living, at least in highincome countries. This paper combines these to pics and explores how economic, demographic and environmental factors have affected the recovery and utilization of recycled paper between 1992 and 2010 in a sample of 70 countries. This study updates and extends the previous research on the topic using panel data and panel data estimation methods. The results confirm the roles of economic determinants but also indicate that concern for the environment impacts the recovery of recycled paper particularly in high-income countries. M oreover, the motives for recycling appear to depend on the income level of a country, which is something that future policies should consider.
\end{abstract}

\section{Keywords}

recycled paper, recovery rate, utilization rate, recycling, paper industry, inter-country differences 
The use of recovered paper ${ }^{1}$ as a raw material for paper and board has been growing faster than that of any other material during recent decades, and the world's recycled paper collection increased by an impressive $575 \%$ between 1970 (30.8 million tons) and 2010 (208 million tons) (FAO, 2012). In more detail, recovered paper collection increased by $64.3 \%$ between 1970 and 1980 , by $66.7 \%$ between 1980 and 1990, by $69.7 \%$ between 1990 and 2000, and by $45.4 \%$ between 2000 and 2010. Thus it appears that the growth has actually been decelerating in the 2000 s. However, paper and board production today uses more recycled than virgin fiber as input (FAO, 2012). This development has been facilitated by technological progress in such areas as deinking and screening of impurities (Diesen, 2007) and by the good price competitiveness of recycled fiber. Recovered paper is cheaper than wood pulp, even in periods of high prices. Currently, recycled paper is used as a raw material when its availability is secured and when its usage is economically rational (Berglund et al., 2002; Berglund and Söderholm, 2003a; M iranda et al., 2010).

In addition, environmental regulation and consciousness at both the producer and consumer level have contributed to the increase in the demand for recovered paper (e.g., Collins, 1998; Lundmark, 2001; Berglund et al., 2002; Berglund and Söderholm, 2003a; Huhtala and Samakovlis, 2002; Samakovlis, 2003; M iranda and Blanco, 2010; M iranda et al., 2010). Through the use of recovered materials, natural resources are saved, emissions reduced and the burden of solid waste becomes smaller (van Beukering and Bouman, 2001). However, the allocation of recycling benefits between virgin and recycled fibers is a difficult question, as recently indicated by Laurijssen et al. (2010) in analyzing $\mathrm{CO}_{2}$ and energy impacts of paper recycling in the Netherlands.

Recent decades have witnessed a surge of interest in environmental issues in many countries. In general, environmental awareness has been promoted by education, e.g., on the potential benefits of recycling (Bolane, 2006). There is also evidence that this awareness manifests itself in a higher recycled paper collection rate in Europe and that environmental awareness is a major determinant of paper recovery in European countries (Miranda and Blanco, 2010). At the same time, higher environmental awareness does not necessarily result in more active recycling in developing countries, where the primary motives for recycling appear to be economic (Cointreau, 1987; Bolane, 2006). This difference highlights that recycled paper recovery and utilization should be analyzed separately for developed high-income countries and developing lower-income countries (see also van Beukering and van den Bergh, 2006).

Despite the skyrocketing use of recovered paper in the paper and board industry and the associated increases in its recovery and utilization, the studies focusing on country-level differences in recycled paper collection and use are rare and their results inconclusive. In addition, the existing studies are mainly from the early years of the 2000s. The recent

${ }^{1}$ The terms recycled paper, recovered paper and waste paper are used interchangeably in this paper. 
changes in paper and board production imply that also the factors behind paper recycling and recovered paper utilization might have changed. This paper attempts to fill the research gap by updating and extending the study of Berglund et al. (2002). In their study, Berglund et al. identify and analyze the most important determinants of inter-country differences in recycled paper recovery and utilization rates. The current study brings the analysis of Berglund et al. up to date using panel data between 1992 and 2010 and by considering country-level differences in environmental awareness. M oreover, separate models are estimated for high-income and lower-income countries due to the apparent differences in the motives for recycling in the two groups of countries. In contrast to Berglund and Söderholm (2003a), who make a distinction between high- and middleincome countries, the current study includes some genuinely low-income countries in the analysis in order to be able to compare countries that are at truly different stages of economic development. The results should be of interest to policymakers who use or plan to use recovery and utilization rates as policy targets. The results could also serve as a starting point for forecasting future patterns in the recovery and utilization of recycled paper.

\section{Recycled Paper Recovery and Utilization}

\subsection{Key Concepts and Recent Trends}

A country's status with respect to recycled paper can be described by two ratios: the recovery rate and the utilization rate (e.g., Grace et al., 1978; Berglund et al., 2002). The recovery rate (RR) measures the supply of recovered paper from domestic sources. This rate is calculated by dividing recovered paper collection ( $\left.\mathrm{RP}_{\text {collect }}\right)$ by total paper and paperboard consumption ( $\mathrm{PB}_{\text {cons, }}$ which is equal to the sum of domestically produced and imported paper and board minus paper and board exports):

$$
R R=\frac{R P_{\text {collect }}}{P B_{\text {cons }}}
$$

The second important ratio, the utilization rate (UR), denotes the extent to which recycled paper is used in paper and board production. This ratio is defined as the ratio of a country's recovered paper consumption $\left(\mathrm{RP}_{\text {cons }}\right)$ and its total domestic paper and board production $\left(\mathrm{PB}_{\text {prod }}\right)$ :

$$
U R=\frac{R P_{\text {cons }}}{P B_{\text {prod }}}
$$

According to a provider of information for the global pulp and paper industry (RISI) (2012) and the authors' calculations, the highest recovery rates of the year 2010 could be found in South Korea (95.8 \%) and Norway (92.1\%), and the lowest recovery rate could be found 
in Peru (15.9\%). The highest recovery rates are made possible for example by packaging paper imports from China and other Far-Eastern countries (M iranda et al., 2010). At the same time, the utilization rate varied from $116 \%$ in El Salvador to $4.9 \%$ in Finland. A country's utilization rate can exceed $100 \%$ if recovered paper is the primary raw material in paper making. In general, the utilization rate tends to peak in Eastern Europe and Southeast Asia, whereas the lowest rates are found in forest-rich Northern countries that are significant exporters of paper and board products. Figure A.1 depicts recovery and utilization rates for the sample of countries analyzed in this study.

The volume of global recycled paper trade has also been on the increase in recent years. M any high-income countries with some of the highest recovery rates (such as Germany, Netherlands, United Kingdom and Japan) are at present exporting very high volumes of recovered paper to developing countries with less paper consumption and less developed recovery schemes. In 2010, China was by far the largest importer of recycled paper with the imports of over 24.7 million tons. (RISI, 2012)

Figures $1 \mathrm{a}$ and $1 \mathrm{~b}$ depict the evolution of recovery and utilization rates between 1992 and 2010 in countries that are at different stages of economic development. The division of countries into high-income countries and lower-middle-income and low-income countries follows the World Bank's country classification (see section 3.3 for details). Figure 1a shows that the recovery rate has been on the increase in both rich and poorer countries. The increase exceeds 20 percentage points in the high-income countries, where the recovery rate was higher already in 1992. The rise is smaller at approximately 15 percentage points in lower-middle-income and low-income countries. These differences between the two groups of countries suggest that different factors might explain their recovery rate, implying that the subsequent recovery rate analysis should be performed separately for rich and poorer countries (see also van Beukering and Bouman, 2001; Berglund and Söderholm, 2003a; 2003b; van Beukering and van den Bergh, 2006). 

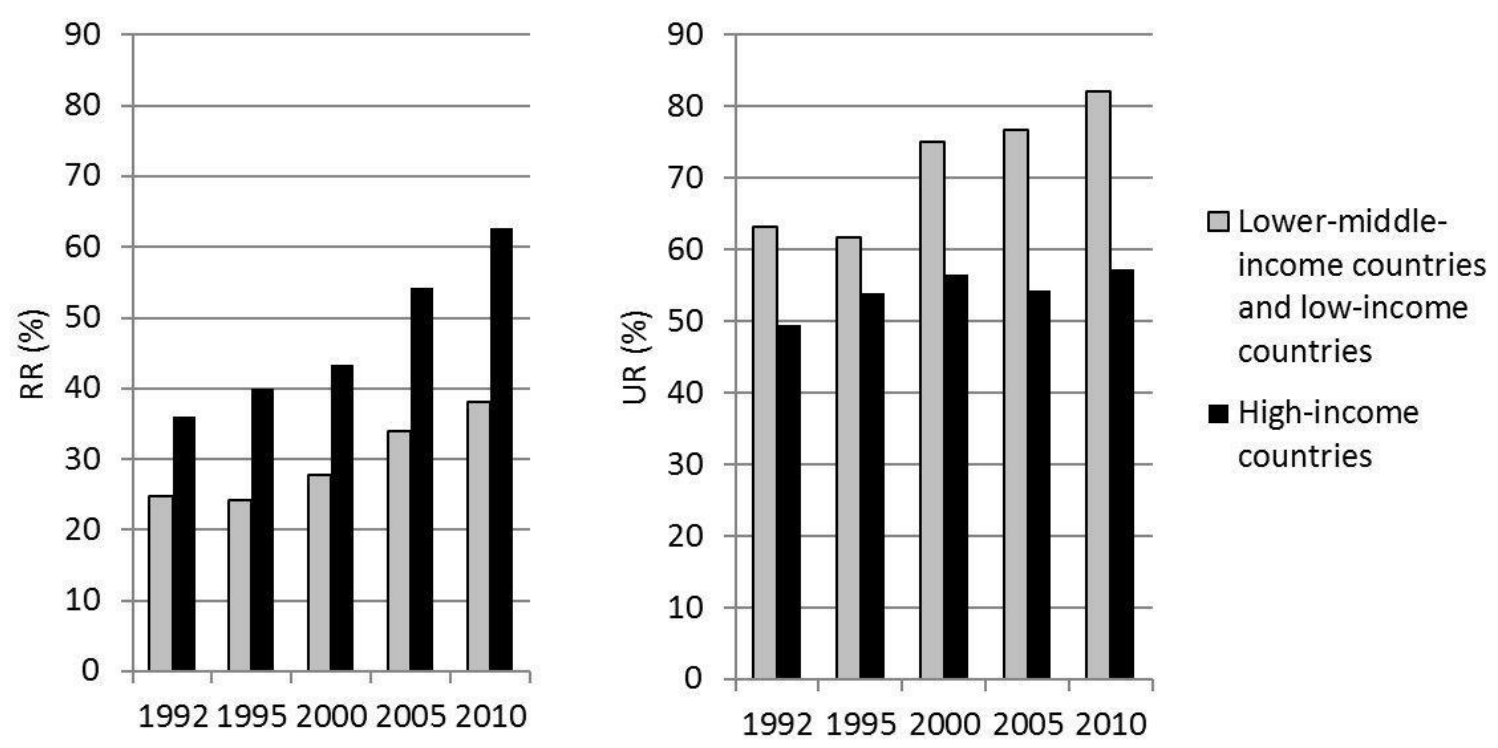

Figures $1 \mathrm{a}$ and $1 \mathrm{~b}$ Recovery and utilization rates by income level.

Figure $1 \mathrm{~b}$ shows the changes in the utilization rate in high-income countries and lowermiddle-income and low-income countries. As seen from the figure, the utilization rate has been higher in developing countries than in developed countries. The utilization rate has also been on the rise in the former, where the upsurge in the utilization rate amounts to approximately 20 percentage points between 1992 and 2010. The simultaneous changes have been much smaller at below 10 percentage po ints in high-income countries. As a result, the recycled paper utilization level has diverged in the two groups of countries during recent years. The figure thus suggests that the level of economic development impacts also the utilization rate, either directly or indirectly.

\subsection{Previous Empirical Econometric Literature}

Some earlier studies (most notably van Beukering and Bouman, 2001; Berglund et al., 2002; Berglund and Söderholm, 2003a; 2003b) have analyzed recycled paper recovery and utilization. Table A.1 in Appendix presents an overview of previous empirical work. The current study concentrates on the studies that have applied econometric techniques and quantitative data in the analysis. In particular, it follows Berglund et al. (2002), who formulate the following model for the recovery rate in country $\mathrm{i}$ :

$$
\ln R R_{i}=\alpha_{0}+\alpha_{1} \ln G D P p c_{i}+\alpha_{2} \ln U R B_{i}+\alpha_{3} \ln P O P_{i} .
$$

The explanatory variables include a country's gross domestic product (GDP) per capita (GDPpC), urban population as \% of the total population (URB, also called urbanization) and population density (POP). The role of GDP per capita in the equation is twofold. First, as GDP per capita increases, also the opportunity costs of labor-intensive activities, such as 
recovery and recycling of waste paper, tend to rise. However, in high-income countries where labor costs are high, sorting of waste paper is nowadays mainly automated. In lowincome countries sorting is still mainly manual, meaning that labor costs continue to play a role. ${ }^{2}$ Second, environmental laws and policies are in general stricter and the recycling infrastructure more advanced in high-income countries, meaning that the recovery rate could also be positively correlated with GDP per capita. Although the empirical results of Berglund et al. (2002) for over 80 countries in 1996 imply that the net effect of GDP per capita on the recovery rate is positive, the authors are unable to estimate the magnitudes of economic and environmental effects separately. The rest of the explanatory variables of equation (3), that is urbanization and population density, capture collection costs of recycled paper. Because the collection system is more cost-effective in densely populated urban areas, both variables are expected to have a positive influence on the recovery rate. The results of Berglund et al. (2002) are in support of this idea although only population density is statistically significant at $\alpha=0.05$ in their estimations. As Berglund et al. note, the insignificance of urbanization might be caused by multicollinearity. Because panel data estimation methods tend to be less prone to multicollinearity, this problem should be eased using panel data.

Berglund and Söderholm (2003a) also include the domestic waste paper price in the recovery rate equation. Unfortunately, panel data on the variable are unavailable for a large enough sample and hence the price cannot be included in the estimations here.

The model of Berglund et al. (2002) for the utilization rate is as follows:

$$
\ln U R_{i}=\beta_{0}+\beta_{1} \ln G D P p c_{i}+\beta_{2} \ln F R_{i}+\beta_{3} \ln P M_{i}+\beta_{4} \ln S E_{i}+\beta_{5} \ln R R_{i} .
$$

The explanatory variables comprise a country's GDP per capita (GDPpc), virgin forest supply (FR), paper product mix (PM ), structural effect (SE) and recovery rate (RR). First, GDPpc is assumed to reflect environmental preferences toward recycling. Berglund et al. (2002) hypothesize that a higher GDP per capita increases people's willingness to pay for recycled paper and board products. Second, FR is the forest growing stock divided by total land area. FR measures the long-run availability of virgin fiber. In general, countries with large forest resources tend to utilize less recovered paper in paper and board production in comparison to countries with scarce forest resources. Third, PM denotes the proportion of newsprint and liner and fluting board in a country's paper and board production. The UR is particularly high in the production of these grades. Fourth, the SE is defined as the ratio of production to consumption of paper and board (\%). In leading paper-producing countries with small domestic markets, the supply of recovered paper is relatively small in contrast to the total demand for raw material in the paper industry. Thus, an increase in the SE should lead to a decrease in the UR. Fifth, the RR measures the availability of recovered paper together with the structural effect and GDPpc. Naturally, a higher RR should lead to a higher UR. Furthermore, people's environmental awareness is assumed

\footnotetext{
${ }^{2}$ We thank a reviewer for pointing this out.
} 
to affect the UR indirectly via the RR rather than directly: "Higher GDP is expected to lead to more intense waste collection and sorting activities undertaken. This gives a higher recovery rate, which in turn stimulates increased use of waste paper" (Berglund et al., 2002, p. 183). To summarize, $B_{1}, b_{3}$ and $B_{5}$ are expected to be positive, and $B_{2}$ and $B_{4}$ are expected to be negative. According to the results of Berglund et al. (2002), almost all of the explanatory variables used in the UR model are statistically insignificant even at $\alpha=0.1$. However, SE is statistically significant at $\alpha=0.01$, suggesting that the recovered paper availability is the most important determinant of the inter-country differences in the utilization rate. This finding is in line with the results of Berglund and Söderholm (2003a).

Overall, Berglund et al. (2002) (and Berglund and Söderholm, 2003a) conclude that the relative recovered paper collection and use depend mostly on long-standing economic characteristics such as population density and comparative advantage in the global paper and paperboard markets, not on environmental policies. Therefore, recovery and utilization rates may only be of limited use as policy measures.

Unlike Berglund et al. (2002), Berglund and Söderholm (2003a) consider the level of economic development and estimate separate models for high-income and middleincome countries. Their results indicate that GDP per capita only affects the recovery rate in richer countries, where recycling activities thus appear to be propelled by environmental concerns. Their results also support the notion that recycled paper recovery has mainly economic motivations in lower-income countries. Furthermore, recycled paper availability appears to be the most important determinant of the utilization rate in both high-income and middle-income countries. The close association with paper and board exports implies that it might be impossible to adjust utilization goals without interfering with the patterns of international trade. The availability of virgin fiber appears to lower the utilization rate only in high-income countries. The explanation for this may be that investment costs for paper recycling technologies are lower than in paper manufacture from virgin paper. Therefore, the availability of virgin fibers would not lessen the utilization rate in low-income countries. ${ }^{3}$

In a related study, van Beukering and Bouman (2001) develop and estimate an empirical model for the recovery and use of recycled paper. Based on panel data from 50 countries during 1970 - 1997, the authors conclude that waste materials recovered in developed countries are increasingly exported for utilization in developing countries. Apart from geographic and economic conditions (such as forest resources, population density, and manufacturing wages), general dependency on foreign trade and net import ratio of recycled paper consistently are found to be positively related to the utilization rate in both developed and developing countries and negatively related to the recovery rate in developing countries. Based on panel data from 49 countries during 1990 - 1996, Berglund and Söderholm (2003b) provide a critical analysis and complementary empirical evidence on the global recycling and trade of recovered paper. These authors question the

${ }^{3}$ We thank a reviewer for pointing this out. 
earlier finding of van Beukering and Bouman (2001) that international trade patterns of recovered paper are a major determinant of the utilization rate and focus instead on the availability of recycled fiber in accordance with Berglund et al. (2002) and Berglund and Söderholm (2003a).

To conclude the literature review, the approaches of Berglund et al. (2002) and van Beukering and Bouman (2001) have a different focus. This study is more closely associated with that of Berglund et al., even if analyzing international trade flows of recycled paper in the spirit of van Beukering and Bouman could also be enlightening. That analysis is, however, a topic for another paper. In the following sections, this study aims to update the analysis of Berglund et al. (2002) by using panel data. Separate models are estimated for high-income and lower-income countries.

\section{$3 \quad$ Research Methodology}

\subsection{Models for the Recovery Rate and the Utilization Rate}

The models presented here are an update of Berglund et al. (2002). First, two models for the recovery rate are estimated:

$$
\begin{aligned}
& R R_{i t}=\alpha_{0}+\alpha_{1} \ln G D P p c_{i t}+\alpha_{2} U R B_{i t}+\alpha_{3} \ln P O P_{i t}+\gamma_{i}+\varepsilon_{i t} \\
& R R_{i t}=\alpha_{0}+\alpha_{1} \ln G D P p c_{i t}+\alpha_{2} U R B_{i t}+\alpha_{3} \ln P O P_{i t}+\alpha_{4} S C H O O L_{i t}+\gamma_{i}+\varepsilon_{i t}
\end{aligned}
$$

The three explanatory variables of equation (5) come from Berglund et al. (2002). GDP per capita (GDPpc) measures the impact of economic factors on the RR. As discussed above, the net effect of GDPpc on the RR may be positive or negative because GDPpc captures both the impact of labor costs on recovery activities and the effect of economic prosperity on environmental attitudes and recycling infrastructure. Urbanization (URB) and population density (POP) measure recycled paper collection costs and are expected to have a positive influence on the RR because the collection system is more cost-effective in densely populated urban areas. Finally, $\gamma_{i}$ is the county-specific fixed effect and $\varepsilon_{i t}$ is the error term. As discussed below in Section 3.2, fixed effects are included here because the $F$ test for fixed effects implies that the countries are different (and that fixed effects estimation therefore outperforms pooled ordinary least squares estimation) and because the Hausman contrast test implies that the random effects estimator is inconsistent (indicating that the fixed effects estimator should be used instead of the random effects estimator).

The model of Berglund et al. (2002) does not account for environmental awareness directly, although e.g., M iranda et al. (2010) and M iranda and Blanco (2010) underline the role of environmental awareness in determining the scope of paper recycling. The results of M iranda and Blanco on how environmental awareness raises the collection rate imply 
that equation (5) can be improved. Therefore, the average years of total schooling (SCHOOL) is included in equation (6) as a proxy for the level of environmental awareness of a country's citizens. According to Klineberg et al. (1998), Bolane (2006) and M arquartPyatt (2008), among others, education increases environmental concern. Therefore, $\mathrm{SCHOOL}$ is expected to have a positive effect on the recovery rate. However, it should be born in mind that schooling is only a proxy for environmental awareness.

Equations (7) and (8) depict the models for the utilization rate. Country-specific fixed effects are included in them for the same reason as in equations (5) and (6).

$$
\begin{aligned}
& U R_{i t}=\beta_{0}+\beta_{1} \ln G D P p c_{i t}+\beta_{2} \ln F A_{i t}+\beta_{3} P M_{i t}+\beta_{4} S E_{i t}+\beta_{5} R R_{i t}+\delta_{i}+\varepsilon_{i t} \\
& U R_{i t}=\beta_{0}+\beta_{1} \ln G D P p c_{i t}+\beta_{2} \ln F A_{i t}+\beta_{3} P M_{i t}+\beta_{4} S E_{i t} \\
& +\beta_{5} R R_{i t}+\beta_{6} \ln P B C O N S_{i t}+\beta_{7} \ln I S O_{i t}+\delta_{i}+\varepsilon_{i t} .
\end{aligned}
$$

The wealthier a country is, the higher is paper consumption (e.g., Hetemäki, 2005; Diesen, 2007) and, hence, the more paper there is to recycle (in tons). In equation (7), GDP per capita is considered as a determinant of recovered paper availability. It is also likely that such utilization of waste that shows in GDP is greater in high-income countries, meaning that $B_{1}$ is expected to be positive. At the same time, countries with very low paper consumption could theoretically obtain very high recycling rates. Therefore, it is important to include not only GDP per capita but also the recovery rate (RR) as an explanatory variable in the model. In order to examine the role of paper and board consumption in recovered paper utilization directly, equation (8) incorporates paper and board consumption (PBCONS) in addition to GDP per capita. The expected sign of $b_{6}$ is positive, because the availability of waste paper to be recovered is likely to result in higher willingness to invest in the utilization of recycled paper. In addition, as discussed above in Section 2.2, also $B_{3}$ and $B_{5}$ are expected to be positive, while $B_{2}$ and $B_{4}$ are expected to be negative.

In model (8), the cumulative number of ISO 14001 certificates per million people (ISO) is included as an indicator for environmental awareness of industry managers. ISO 14001 is a standard for environmental management systems and has previously been used in the context of a recovered paper utilization analysis by $M$ iranda and Blanco (2010). In the model used here, the diffusion of certificates measures the environmental awareness in the paper industry, where an increasing number of certificates should indicate higher utilization rates of recovered paper. Thus, $b_{7}$ is expected to be positive.

\subsection{Estimation Methodology}

Two basic estimation methods for panel data are the fixed effects (FE) model and the random effects (RE) model. In FE models, unobservable country-specific effects (denoted by $\gamma_{i}$ in equations (5) and (6) and by $\delta_{i}$ in equations (7) and (8)) are assumed to be fixed 
parameters to be estimated or are eliminated using the so-called within estimator. The explanatory variables are assumed to be independent of the error term $\varepsilon_{i t}$; however, the country-specific effects are permitted to correlate with the regressors. In RE estimation, $\gamma_{i}$ and $\delta_{\mathrm{i}}$ are assumed to be random and act as a part of the error term together with $\varepsilon_{\mathrm{it}}$. For the RE estimator to be consistent, the explanatory variables must be independent of both $\gamma_{i}$ and $\delta_{i}$ and $\varepsilon_{i t}$ for all $i$ and t. For further information see, for example, Baltagi (2005).

The Hausman (1978) contrast test is used here to examine whether the RE estimator is consistent. If the null hypothesis that all the explanatory variables are exogenous is rejected, the RE estimator is inconsistent and the FE estimator has to be used. Because the RE estimator is inconsistent in all the models discussed in the next section apart from model (3) in Table 6, FE estimation results are reported. All estimations have been conducted with Stata/ IC software (version 11 for Windows).

\subsection{Data Description}

The data are annual country-level panel data for the period 1992 - 2010. The number of countries included in the estimations is in total 70, of which 33 are high-income countries and 12 are lower-middle-income or low-income countries. The classifications originate from the World Bank's World Development Indicators database (as of June 2012). At the time of writing, countries are divided into income groups in accordance with 2011 gross national income per capita, which is calculated using the World Bank Atlas method. The groups and their income limits are the following: (1) low-income, $\$ 1025$ or less; (2a) lower-middle-income, \$1026 - \$4035; (2b) upper-middle-income, \$4036 - \$12475; and (4) high-income, $\$ 12476$ or more (see also http://data.worldbank.org/about/ countryclassifications).The most important recovered paper producer and consumer countries all over the world are included in the data set.

Data for this study were collected from various databases. Table 1 summarizes the variables, their definitions and data sources. 
Table $1 \quad$ Variables, definitions and data sources

\begin{tabular}{|c|c|c|}
\hline Variable & Definition & Data source \\
\hline Recovery rate (RR) & $\begin{array}{l}\text { Recovered paper collection } \\
\text { divided by total paper and } \\
\text { paperboard consumption (\%) }\end{array}$ & $\begin{array}{l}\text { Industry Statistics database, } \\
\text { RISI (2012) }\end{array}$ \\
\hline Utilization rate (UR) & $\begin{array}{l}\text { The ratio of a country's } \\
\text { recovered paper consumption } \\
\text { and its total domestic paper } \\
\text { and board production (\%) }\end{array}$ & $\begin{array}{l}\text { Industry Statistics database, } \\
\text { RISI (2012) }\end{array}$ \\
\hline GDP per capita (GDPpc) & $\begin{array}{l}\text { GDP per capita (constant } 2000 \\
\text { USD) }\end{array}$ & $\begin{array}{l}\text { World Development Indicators } \\
\text { database (WDI), World Bank } \\
\text { (2012) }\end{array}$ \\
\hline $\begin{array}{l}\text { Paper consumption } \\
\text { (PBCONS) }\end{array}$ & $\begin{array}{l}\text { The apparent consumption } \\
\text { (production + imports - } \\
\text { exports) of paper and } \\
\text { paperboard (1000 tons) }\end{array}$ & $\begin{array}{l}\text { Industry Statistics database, } \\
\text { RISI (2012) }\end{array}$ \\
\hline Urbanization rate (URB) & $\begin{array}{l}\text { Urban population divided by } \\
\text { total population (\%) }\end{array}$ & $\begin{array}{l}\text { World Development Indicators } \\
\text { database (WDI), World Bank } \\
\text { (2012) }\end{array}$ \\
\hline Population density (POP) & $\begin{array}{l}\text { Number of people per sq. } \mathrm{km} \\
\text { of land area }\end{array}$ & $\begin{array}{l}\text { World Development Indicators } \\
\text { database (WDI), World Bank } \\
\text { (2012) }\end{array}$ \\
\hline Schooling (SCHOOL) & $\begin{array}{l}\text { Average years of total } \\
\text { schooling of the population } \\
\text { aged } 15 \text { and over }\end{array}$ & $\begin{array}{l}\text { Barro-Lee data set "A new } \\
\text { Data Set of Educational } \\
\text { attainment in the World, 1950- } \\
\text { 2010" }\end{array}$ \\
\hline Forest area $(F A)^{a}$ & Forest area (sq. km) & $\begin{array}{l}\text { World Development Indicators } \\
\text { database (WDI), World Bank } \\
\text { (2012) }\end{array}$ \\
\hline Paper product mix (PM) & $\begin{array}{l}\text { The proportion of newsprint, } \\
\text { tissue, and packaging paper } \\
\text { and board in a country's paper } \\
\text { and board production (\%) }\end{array}$ & $\begin{array}{l}\text { Industry Statistics database, } \\
\text { RISI (2012) }\end{array}$ \\
\hline Structural effect (SE) & $\begin{array}{l}\text { The ratio of production to } \\
\text { consumption of paper and } \\
\text { board (\%) }\end{array}$ & $\begin{array}{l}\text { Industry Statistics database, } \\
\text { RISI (2012) }\end{array}$ \\
\hline $\begin{array}{l}\text { ISO } 14001 \text { certificates } \\
\text { (ISO) }\end{array}$ & $\begin{array}{l}\text { Cumulative number of ISO } \\
14001 \text { certificates per million } \\
\text { people }\end{array}$ & $\begin{array}{l}\text { The ISO Survey of } \\
\text { Certifications } 2010 \text { by } \\
\text { International Organization for } \\
\text { Standardization }\end{array}$ \\
\hline
\end{tabular}

a Because forest area was only available for 2000, 2005 and 2010, the variable was interpolated and extrapolated for the other years of the sample. 
The summary statistics are presented in Table 2. The statistics are reported separately for (1) all countries, (2) high-income countries and (3) lower-middle-income and low-income countries because the empirical estimations of Section 4 are also performed separately for these catego ries. The classification follows that of the World Bank (2012). A correlation matrix is presented in Appendix in Table A.2. 
Table $2 \quad$ Summary statistics

\begin{tabular}{llrrrr}
$\begin{array}{l}\text { All countries } \\
\text { Variable }\end{array}$ & Obs & \multicolumn{1}{c}{ Mean } & \multicolumn{1}{c}{ Std. Dev. } & \multicolumn{1}{c}{ M in } & \multicolumn{1}{c}{ Max } \\
\hline Recovery rate (RR) (\%) & 1330 & 39.5 & 17.0 & 3.8 & $122.4^{\text {a }}$ \\
Utilization rate (UR) (\%) & 1324 & 60.0 & 25.6 & 0.0 & 125.4 \\
GDP per capita (USD) & 1315 & 10397 & 11017 & 253 & 41904 \\
Paper consumption (1000 tn.) & 1330 & 4545 & 12413 & 38 & 94833 \\
Urbanization (\%) & 1327 & 66.2 & 18.2 & 15.1 & 98.4 \\
Population density (people/sq. km) & 1319 & 129.9 & 155.7 & 2.3 & 1142.3 \\
Schooling (years) & 1292 & 8.7 & 2.3 & 3.0 & 13.1 \\
Forest area (sq. km) & 1330 & 442344 & 1249476 & 34.0 & 8100354 \\
Paper product mix (\%) & 1324 & 73.4 & 17.8 & 0.0 & 100.0 \\
Structural effect (\%) & 1330 & 94.1 & 105.8 & 0.0 & 849.2 \\
ISO 14001 cert. (per million people) & 974 & 0.02 & 0.04 & 0.0000001 & 0.40 \\
\hline
\end{tabular}

\section{High-income countries}

\begin{tabular}{lcrrrr} 
Variable & Obs & \multicolumn{1}{c}{ Mean } & Std. Dev. & \multicolumn{1}{c}{ M in } & \multicolumn{1}{c}{ Max } \\
\hline Recovery rate (RR) (\%) & 627 & 48.3 & 17.2 & 9.3 & $122.4^{\mathrm{a}}$ \\
Utilization rate (UR) (\%) & 621 & 54.6 & 27.6 & 0.0 & 125.4 \\
GDP per capita (USD) & 613 & 19397 & 10217 & 2857 & 41904 \\
Paper consumption (1000 tn.) & 627 & 6629 & 15440 & 38 & 94833 \\
Urbanization (\%) & 624 & 73.7 & 12.2 & 48.0 & 98.4 \\
Population density (people/sq. km) & 616 & 132.3 & 126.2 & 2.3 & 508.9 \\
Schooling (years) & 627 & 10.1 & 1.6 & 5.8 & 13.1 \\
Forest area (sq. km) & 627 & 289405 & 750582 & 34 & 3101340 \\
Paper product mix (\%) & 621 & 69.4 & 19.8 & 0.0 & 100.0 \\
Structural effect (\%) & 627 & 125.6 & 143.5 & 0.0 & 849.2 \\
ISO 14001 cert. (per million people) & 497 & 0.03 & 0.05 & $3.8 \mathrm{E}-07$ & 0.40 \\
\hline
\end{tabular}

\section{Lower-middle-income and low-income countries}

\begin{tabular}{lcrrrr} 
Variable & Obs & \multicolumn{1}{c}{ M ean } & Std. Dev. & \multicolumn{1}{c}{ M in } & \multicolumn{1}{c}{ Max } \\
\hline Recovery rate (RR) (\%) & 228 & 30.0 & 12.8 & 6.0 & 82.6 \\
Utilization rate (UR) (\%) & 228 & 72.8 & 21.9 & 29.6 & 120.0 \\
GDP per capita (USD) & 228 & 1041 & 578 & 253 & 2630 \\
Paper consumption (1000 tn.) & 228 & 1368 & 1951 & 88 & 10776 \\
Urbanization (\%) & 228 & 41.3 & 15.8 & 15.1 & 68.1 \\
Population density (people/sq. km) & 228 & 258.8 & 247.9 & 57.5 & 1142.3 \\
Schooling (years) & 228 & 6.1 & 2.4 & 3.0 & 11.1 \\
Forest area (sq. km) & 228 & 173480 & 300702 & 462 & 1018922 \\
Paper product mix (\%) & 228 & 71.8 & 12.9 & 38.7 & 96.7 \\
Structural effect (\%) & 228 & 61.2 & 38.2 & 11.4 & 230.2 \\
ISO 14001 cert. (per million people) & 152 & 0.0006 & 0.00090 & 0.0000001 & 0.004 \\
\hline
\end{tabular}

${ }^{a}$ The recovery rate is $122.4 \%$ for Ireland in 2009. Ireland does not produce paper or board but is reliant on foreign imports. Between 2008 and 2009, Ireland's paper and board imports decreased from 513 thousand tons to 385 tons due to economic recession. However, the collection of recovered paper remained approximately the same (about 455 thousand tons) between 2008 and 2009 and did not decrease until 
2010. Thus, the recovery rate in 2009 is higher than normally. The next highest recovery rates in the sample are under $100 \%$.

\section{$4 \quad$ Results and Discussion}

Tables 3 - 6 present the results of the FE estimations. T statistics based on robust standard errors are reported throughout.

\subsection{Recovery Rate}

Table 3 is an update on Berglund et al. (2002) Table 4, Column 2. The analysis differs from Berglund et al. in three ways. First, here panel data and the FE estimator are used while Berglund et al. use cross-sectional data and ordinary least squares (OLS) as the estimation method. ${ }^{4}$ Further, this study employs the FE estimator instead of pooled OLS because the F-test for no fixed effects implies that fixed effects differ between the countries in the samples. As mentioned above, only the results for the FE estimator are reported because the Hausman specification test implies that the RE estimator is inconsistent in all models apart from one. Second, the data of Berglund et al. come (mostly) from the year 1996, while the panel data used here cover the years 1992 - 2010. Third, unlike in Berglund et al., here the model is estimated separately for all countries, high-income countries, and lower-middle-income and low-income countries. As discussed above, this division by income level is important because the earlier literature suggests that paper recycling and particularly recovery patterns differ greatly between high-income and low-income countries (e.g., Van Beukering and Bouman, 2001, Berglund and Söderholm, 2003a; Bolane, 2006; M iranda and Blanco, 2010). Moreover, unlike in Berglund and Söderholm (2003a), in this study a model is estimated for lower-middle-income and low-income countries (instead of middle-income countries) in order to have a larger contrast between the two categories of countries and because data for lower-middle-income and lowincome countries were also available.

\footnotetext{
${ }^{4}$ Van Beukering and Bouman (2001) and Berglund and Söderholm (2003a) use panel data; however, the authors pool the data and do not use panel data estimation methods. Moreover, the model of Van Beukering and Bouman is quite different from the models used here, and it is therefore difficult to compare the results.
} 
Table 3 Recovery rate models based on Berglund et al. (2002)

$\begin{array}{lll}\text { (1) all countries } & \begin{array}{l}\text { (2) high-income } \\ \text { countries }\end{array} & \begin{array}{l}\text { (3) lower- } \\ \text { middle-income } \\ \text { and low-income } \\ \text { countries }\end{array}\end{array}$

\begin{tabular}{llll}
\hline (log of) GDP per capita & $18.698^{* * *}$ & $30.767^{* * *}$ & 11.062 \\
& $(4.05)$ & $(4.87)$ & $(0.81)$ \\
urbanization & 0.307 & $2.617^{* *}$ & 0.748 \\
& $(0.77)$ & $(2.71)$ & $(1.04)$ \\
(log of) population density & $21.944^{* *}$ & $26.735^{* *}$ & 14.354 \\
& $(2.04)$ & $(2.10)$ & $(1.52)$ \\
constant & $-234.112^{* * *}$ & $-556.348^{* * *}$ & -151.093 \\
& $(-4.89)$ & $(-7.20)$ & $(-1.59)$ \\
\hline observations & 1307 & 605 & 228 \\
number of groups & 70 & 33 & 12 \\
$\mathrm{R}^{2}$ (within) & 0.2646 & 0.4921 & 0.3190 \\
\hline
\end{tabular}

Notes: robust t statistics in parentheses (* significant at $\alpha=0.1$; ** significant at $\alpha=0.05$; $* * *$ significant at $\alpha=0.01$ )

M odel 1 for all countries supports the results of Berglund et al. (2002). The estimated coefficient of GDP per capita is statistically significant at $\alpha=0.01$ and positive. Berglund et al. speculate that this finding could suggest that recycled paper recovery can be considered to be a luxury good: more value is put on environmental issues in richer countries. However, the result might also be associated with the better recycling infrastructure of high-income countries. The cost effect resulting from the higher opportunity cost of labor in richer countries appears to be relatively less important, which might reflect the auto mation of sorting activities in high-income countries. Additionally, the rest of the results are in line with Berglund et al.: population density is statistically significant at $\alpha=0.05$ and has the expected positive sign. This finding highlights the role of recycled paper recovery costs. In contrast, urbanization is not statistically significant even at $\alpha=0.1$. Overall, these results suggest that the implications of Berglund et al. do not depend on the estimation method or timeliness of the data.

Model 2 has been estimated for the high-income countries only. GDP per capita and population density continue to have a statistically significant positive impact on the recovery rate at least at $\alpha=0.05$. Unlike in M odel 1 , urbanization is also statistically significant at $\alpha=0.05$ and has the expected positive sign, indicating that the costs of separating and collecting recycled paper are important in determining the recovery rate in high-income countries. In contrast, the positive and statistically highly significant coefficient of GDP per capita can be interpreted to underline the effect of economic prosperity on environmental attitudes and recycling infrastructure. In addition, as discussed above, increased automation in sorting of waste paper is likely to have mitigated the labor-cost effect in rich countries. 
In contrast to Model 2, Model 3 for the lower-middle-income and low-income countries does not have any statistically significant explanatory variables, even at $\alpha=0.1$. This lack of statistically significant explanatory variables has at least three possible explanations. First, the category includes a relatively diverse group of countries at different stages of economic development, implying that also the relationship between the recovery rate and the explanatory variables may differ. Second, as Berglund and Söderholm (2003a) hypothesize, it is possible that paper recycling is more informal in low-income countries and thus is not captured well by the official statistics. Third, the number of countries in this category is only 12 , which is enough for FE estimation but may affect the statistical significance of the regressors. Overall, the estimation results cannot be used to deduce whether economic motives for paper recycling overrule other motives in low-income countries.

Because the earlier literature (e.g., Klineberg et al., 1998; Bolane, 2006; M arquart-Pyatt, 2008 ) indicates that education increases environmental awareness, Table 4 based on equation (6) adds the average years of total schooling into the set of explanatory variables. According to the results, education is an important determinant of the recovery rate: the variable schooling is statistically significant at $\alpha=0.01$ both in all countries and high-income countries. If schooling really is a good proxy for environmental awareness, this result indicates that a higher level of environmental awareness has a positive impact on the recovery rate. Also GDP per capita is statistically significant at $\alpha=0.05$ (all countries) or $\alpha=0.01$ (high-income countries) with a positive sign. This result is in line with the results presented in Table 3. In contrast, population density is statistically insignificant if the impact of schooling is accounted for. If education is seen to reflect in environmental attitudes, this result indicates that environmental concerns might overrule economic motives at least to some extent in developed countries. Such conclusion is in support of Miranda and Blanco (2010). Urbanization continues to be statistically significant at $\alpha=0.05$ with a positive coefficient for high-income countries. In contrast, all the explanatory variables are again statistically insignificant, even at $\alpha=0.1$, in M odel 3 for lower-middleincome and low-income countries. The insignificance of schooling in Model 3 is in line with the assertion that the motives for recovering waste paper are mainly economic in poorer countries (e.g., Cointreau, 1987; Bolane, 2006). 
Table $4 \quad$ M odified recovery rate models with average years of schooling included

\begin{tabular}{lccc} 
& (1) all countries & $\begin{array}{l}\text { (2) high-income } \\
\text { countries }\end{array}$ & $\begin{array}{l}\text { (3) lower- } \\
\text { middle-income } \\
\text { and low-income } \\
\text { countries }\end{array}$ \\
\hline (log of) GDP per capita & $12.723^{* *}$ & $20.481^{* * *}$ & 11.176 \\
& $(2.33)$ & $(3.08)$ & $(0.67)$ \\
urbanization & 0.103 & $2.170^{* *}$ & 0.751 \\
& $(0.26)$ & $(2.58)$ & $(0.99)$ \\
(log of) population density & 11.031 & 14.369 & 14.528 \\
& $(1.04)$ & $(1.07)$ & $(0.98)$ \\
average years of total schooling & $4.746 * * *$ & $6.145^{* * *}$ & -0.071 \\
& $(2.93)$ & $(3.31)$ & $(-0.01)$ \\
constant & $-163.961 * * *$ & $-432.830^{* * *}$ & -152.446 \\
& $(-2.96)$ & $(-5.05)$ & $(-1.09)$ \\
\hline observations & 1269 & 605 & 228 \\
number of groups & 68 & 33 & 12 \\
$\mathrm{R}^{2}$ (within) & 0.3150 & 0.5282 & 0.3190 \\
\hline \multicolumn{2}{c}{ Notes: robust t statistics in parenthes (* significant at $\alpha=0.1 ; * *$ significant at $\alpha=0.05 ;$} \\
$* * *$ significant at $\alpha=0.01)$ & & &
\end{tabular}

\subsection{Utilization Rate}

Table 5 reports the results for the utilization rate based on equation (7). Berglund et al. (2002) use an instrumental variable estimation for their utilization rate model because they find the recovery rate to be endogenous, in which case OLS estimates of the model parameters would be inconsistent. However, in the current study endogeneity tests imply that the recovery rate is exogenous in the models (the results are available upon request from the authors). Therefore, the results for standard FE estimations are presented in Table 5. The other significant differences between the approaches in this study and Berglund et al.'s are that here panel data is used and that the data are more recent. Berglund and Söderholm (2003b) also estimate a utilization rate equation with panel data between 1990 and 1996 but use pooled OLS as the estimation method. The authors estimate separate equations for high-income and middle-income countries. 
Table $5 \quad$ Utilization rate models based on Berglund et al. (2002)

\begin{tabular}{|c|c|c|c|}
\hline & (1) all countries & $\begin{array}{l}\text { (2) high-income } \\
\text { countries }\end{array}$ & $\begin{array}{l}\text { (3) lower- } \\
\text { middle-income } \\
\text { and low-income } \\
\text { countries }\end{array}$ \\
\hline (log of) GDP per capita & $\begin{array}{l}8.761^{* *} \\
(2.37)\end{array}$ & $\begin{array}{r}0.130 \\
(0.02)\end{array}$ & $\begin{array}{l}23.465^{* * *} \\
(4.16)\end{array}$ \\
\hline (log of) forest area & $\begin{array}{l}-11.462 \\
(-0.78)\end{array}$ & $\begin{array}{l}-4.365 \\
(-0.15)\end{array}$ & $\begin{array}{l}-32.511^{* *} \\
(-2.28)\end{array}$ \\
\hline paper product mix & $\begin{array}{l}0.513^{* * *} \\
(5.50)\end{array}$ & $\begin{array}{l}0.702 * * * \\
(6.18)\end{array}$ & $\begin{array}{c}0.191 \\
(1.65)\end{array}$ \\
\hline structural effect & $\begin{array}{l}-0.151^{* * *} \\
(-2.92)\end{array}$ & $\begin{array}{l}-0.044 \\
(-1.59)\end{array}$ & $\begin{array}{l}-0.277 \\
(-1.32)\end{array}$ \\
\hline recovery rate & $\begin{array}{l}0.426 * * * \\
(6.18)\end{array}$ & $\begin{array}{l}0.335^{* * *} \\
(4.41)\end{array}$ & $\begin{array}{l}0.297 * \\
(1.91)\end{array}$ \\
\hline constant & $\begin{array}{l}70.357 \\
(0.45)\end{array}$ & $\begin{array}{l}39.907 \\
(0.13)\end{array}$ & $\begin{array}{l}251.673 \\
(1.50)\end{array}$ \\
\hline observations & 1309 & 607 & 228 \\
\hline number of groups & 70 & 33 & 12 \\
\hline$R^{2}$ (within) & 0.4272 & 0.3494 & 0.5681 \\
\hline
\end{tabular}

In the model estimated by Berglund et al. (2002), GDP per capita, forest area and paper product mix were all statistically insignificant. In the current study, however, GDP per capita is statistically significant at $\alpha=0.05$ and paper product mix at $\alpha=0.01$ (M odel 1 ). The positive coefficient of GDP per capita indicates that the availability of recycled paper impacts the utilization rate: the higher per capita paper consumption in richer countries improves the availability of paper to be recovered, which is then reflected in a higher utilization rate. This interpretation is supported by the positive and statistically highly significant coefficients of recovery rate and structural effect. Additionally, high GDP per capita may reflect higher incentives to utilize recycled paper. The positive coefficient of paper product mix implies that the composition of paper and board production is also important: the larger is the share of those end products that use recycled paper as an in put intensively, the higher is the utilization rate. Similar to Berglund et al., forest area is also insignificant in the model of this study, implying that the substitution effect of virgin fiber is not that important.

There are some similarities between the results of the current study and the studies of Berglund et al. (2002) and Berglund and Söderholm (2003a; 2003b). Namely, the usage of recovered paper appears to depend heavily on the sufficiency of domestic recycled paper 
measured by structural effect and recovery rate. Thus it appears that recycled-paper utilization is driven by markets. Furthermore, the results of this study imply that the paper grades being produced in a country also play a role.

M odels 2 and 3 can be used to assess the differences between high-income and lowincome countries. It should be noted that all the coefficients are again (as in M odel 1) of the expected signs, although not all coefficients are statistically significant even at $\alpha=0.1$. In particular, the statistically significant variables are mostly different in M odels 2 and 3, indicating that different factors influence the utilization rate in high-income countries and in lower-middle-income and low-income countries. Although Berglund and Söderholm (2003a) hypothesized that the differences between the two groups of countries should be smaller in the case of the utilization rate in comparison to the recovery rate, the results of this study imply that this is not the case when using panel data from 1992 to 2010.

In Model 2 for high-income countries, only paper product mix and recovery rate are statistically significant. As in the case of all countries, the positive coefficients of paper product mix and recovery rate indicate that the composition of paper and board production and the supply of recovered paper impact the usage of recycled fiber. The availability of virgin fiber as well as GDP per capita do not appear to play any role. The insignificance of GDP per capita in the high-income countries might reflect the stagnating demand for paper in these countries: higher GDP per capita might not affect the availability of recycled paper after a certain income threshold.

According to Model 3 for lower-income countries, GDP per capita, forest area and recovery rate are statistically significant. The coefficients of all three variables are of the expected sign. The more virgin fiber there is available, the lower is the utilization rate. Interestingly, this effect is only visible in lower-middle-income and low-income countries. This finding is in contrast with the results of Berglund and Söderholm (2003a) and what was hypothesized in section 2.2 on the relative investment costs of paper recycling technologies and paper manufacture from virgin paper. It might however be the case that the existing paper machines are better suited for using virgin fiber instead of recycled fiber in developing countries. In that case, updating the technology may have been deemed unprofitable if virgin fiber is available and the demand for more environmentally friendly products is low in local markets. Instead, the supply of recycled paper (measured by the recovery rate and the structural effect) appears to be less significant in poor countries. A potential explanation is that recycled paper availability could already be captured by GDP per capita because paper consumption could still be on the increase in lower-income countries.

Table 6 depicts the results for model (8) with paper and board consumption and the diffusion of ISO 14001 certificates as explanatory variables. Paper and board consumption (i.e. the availability of paper to be recovered) does not seem to affect the utilization rate in any of the models. Also the diffusion of ISO 14001 certificates is statistically insignificant even at $\alpha=0.1$ in all three models. The result might reflect the fact that the total number of 
ISO 14001 certificates in a country covers all industries but the relative size of the paper industry varies between countries. This insignificance of ISO certificates is in line with M iranda and Blanco (2010) who report only a very weak positive relationship with the recycled paper collection rate (not utilization rate) and ISO 14001 certifications.

Table 6 Modified utilization rate models with paper demand and ISO 14001 included

\begin{tabular}{|c|c|c|c|}
\hline & (1) all countries & $\begin{array}{l}\text { (2) high-income } \\
\text { countries }\end{array}$ & $\begin{array}{l}\text { (3) lower- } \\
\text { middle-income } \\
\text { and low-income } \\
\text { countries }\end{array}$ \\
\hline (log of) GDP per capita & $\begin{array}{r}7.697 \\
(1.42)\end{array}$ & $\begin{array}{r}6.225 \\
(0.98)\end{array}$ & $\begin{array}{l}32.786^{* *} \\
(2.40)\end{array}$ \\
\hline (log of) forest area & $\begin{array}{l}-19.181 \\
(-1.10)\end{array}$ & $\begin{array}{l}-19.273 \\
(-0.39)\end{array}$ & $\begin{array}{l}-13.803 \\
(-0.55)\end{array}$ \\
\hline paper product mix & $\begin{array}{l}0.667 * * * \\
(6.40)\end{array}$ & $\begin{array}{l}0.748^{* * *} \\
(5.97)\end{array}$ & $\begin{array}{r}0.274 \\
(1.68)\end{array}$ \\
\hline structural effect & $\begin{array}{l}-0.057^{*} \\
(-1.85)\end{array}$ & $\begin{array}{l}-0.044 \\
(-1.58)\end{array}$ & $\begin{array}{l}-0.057 \\
(-0.44)\end{array}$ \\
\hline recovery rate & $\begin{array}{l}0.315^{* * *} \\
(5.20)\end{array}$ & $\begin{array}{l}0.224 * * * \\
(3.09)\end{array}$ & $\begin{array}{r}0.032 \\
(0.68)\end{array}$ \\
\hline (log of) paper consumption & $\begin{array}{l}-0.981 \\
(-0.26)\end{array}$ & $\begin{array}{l}-4.841 \\
(-1.38)\end{array}$ & $\begin{array}{l}-15.816 \\
(-1.03)\end{array}$ \\
\hline (log of) ISO 14001 certificates & $\begin{array}{l}-0.039 \\
(-0.15)\end{array}$ & $\begin{array}{l}-0.002 \\
(-0.01)\end{array}$ & $\begin{array}{c}0.888 \\
(0.76)\end{array}$ \\
\hline constant & $\begin{array}{l}155.150 \\
(0.80)\end{array}$ & $\begin{array}{l}179.498 \\
(0.33)\end{array}$ & $\begin{array}{l}97.778 \\
(0.31)\end{array}$ \\
\hline observations & 962 & 486 & 152 \\
\hline number of groups & 70 & 33 & 12 \\
\hline$R^{2}$ (within) & 0.3930 & 0.4474 & 0.3405 \\
\hline
\end{tabular}

Notes: robust t statistics in parentheses (* significant at $\alpha=0.1 ; * *$ significant at $\alpha=0.05$; $* * *$ significant at $\alpha=0.01$ ). According to endogeneity tests, $\mathrm{RR}$ is exogenous in all three models. The excluded instrument in the tests was urbanization.

In light of the results of Table 6 , the most robust determinants of the utilization rate seem to be paper product mix and recovery rate (all countries and high-income countries), structural effect (all countries) and the level of economic development (lower-middleincome and low-income countries). The signs of these variables are the same in Tables 5 and 6. As discussed above, the results for all countries indicate thus that the use of recycled paper depends mainly on the availability of domestic recovered paper but that the paper grades being produced also play a role. The same holds for high-income countries. In contrast, in lower-middle-income and low-income countries, GDP per capita appears to capture recycled paper availability. 


\subsection{Summary of the Results}

In accordance with the previous empirical research, the results imply that both economic and demographic factors are important determinants of the recovery and utilization rates. In addition, environmental awareness could also play a role: according to the results, increases in the proxy variable for environmental awareness, i.e. average years of schooling, boost the recovery of recycled paper. In contrast, the results imply that the utilization rate is highly dependent on the demand and supply of recovered paper in paper and board production but not on managerial environmental awareness, as measured by the diffusion of ISO 14001 certificates.

The separate results for high-income and lower-income countries with respect to the recovery rate imply that environmental concerns might overrule economic motives, at least to a certain extent, in richer countries. In contrast, there is no evidence for any impact of environmental awareness on the recovery rate in poorer countries, where the motives for recycling paper could thus be mainly economic. Different factors appear to affect also the utilization rate in high-income and lower-income countries. In rich countries, the composition of paper and board production and the supply of recycled paper have an influence on the usage of recycled fiber. The insignificance of GDP per capita might reflect the stagnating demand for paper in these countries. In low-income countries, GDP per capita, forest area and recovery rate impact the utilization rate, indicating that the availability of recycled paper and virgin fiber determine recycled paper utilization together. The impact of GDP per capita on the utilization rate is the most robust one in these countries.

\subsection{Conclusions}

Electronic devices and the Internet should, in principle, decrease the need for using paper for communication and as a store of information. The growth of graphic paper consumption has indeed flattened in the Western world. However, due to the growth of global trade, the use of packaging papers is increasing around the world. Because of the limitations in virgin fiber availability, growing paper consumption boosts the demand for alternative raw materials in paper production. This increase is also reflected in the consumption of recovered paper, which has grown together with paper consumption. While paper recovery closely follows paper consumption at the global level, the recovery and utilization rates of recycled paper vary greatly between countries with different income levels, quality of infrastructure and social structures.

As global paper consumption is still growing and recovery and use of recycled paper continue to be far from the potential in many countries, it may be necessary to find new approaches to increase recovered paper collection and utilization to meet the increasing demand for raw materials in the paper industry. From an economic perspective, introduction of more efficient recycling systems could also bring out new business opportunities in the so-called base-of-the-pyramid (BoP) countries (Pralahad and 
Hammond, 2002). However, as Berglund and Söderholm (2003a) underline, paper recycling in itself should not be the goal because too strict regulations may sometimes result in actions that harm the environment (such as transporting recycled paper over excessive distances in the ecological sense).

The level of environmental conscio usness varies across countries. Along with the previous empirical evidence, the findings of this study could facilitate the tailoring of national and international policies and incentives, particularly for the collection of recovered paper in high-income countries. At the same time, another approach might work better in developing countries, where the motives for recycling appear to be different. As mentioned above, more efficient paper recycling systems could create business opportunities in the growing BoP markets. However, according to Hart and Dowell (2011), managerial resources and capabilities required to enter and succeed in these markets are likely to differ greatly from the perspective of pollution prevention or product stewardship in environmental management of the developed industrial countries. Due to changing production and consumption patterns of the world's recovered paper markets, the ability to forecast future recovery and utilization rates would further ease planning, making it an interesting topic for further study.

\section{References}

Baltagi BH. Econometric analysis of panel data. 3rd ed. Chichester, UK: Wiley; 2005.

Barro R, Lee J-W. A new data set of educational attainment in the world, 1950-2010. NBER Working Paper No. 159022010.

Berglund C, Söderholm P, Nilsson M. A note on inter-country differences in waste paper recovery and utilization. Resour Conserv Recy 2002;34:175-91.

Berglund C, Söderholm P. An econometric analysis of global waste paper recovery and utilization. Environ Resour Econ 2003a;26:429-56.

Berglund C, Söderholm P. Complementing empirical evidence on global recycling and trade of waste paper. World Dev 2003b;31:743-754.

Bolane B. Constraints to promoting people centred approaches in recycling. Habitat Int 2006;30:731-40.

Cointreau SJ. Solid waste recycling: Case studies in developing countries. Washington, D.C.: World Bank; 1987.

Collins L. Environmentalism and restructuring of the global pulp and paper industry. Tijdschr Econ Soc Ge 1998;89:401-15. 
Diesen M. Economics of the pulp and paper industry - Paper making science and technology book 1. Jyväskylä, Finland: Paperi ja Puu Oy; 2007.

FAO. ForesSTAT database 2012 [cited 2012 Dec 4]. Available from: http:// faostat.fao.org/ site/626/ default.aspx\#ancor

Grace R, Turner RK, Walter I. Secondary materials and international trade. J Environ Econ Manag 1978;5:172-86.

Hausman JA. Specification tests in econometrics. Econometrica 1978;46: 1251-1271.

Hart SL, Dowell G. A natural-resource-based view of the firm: Fifteen years after. J Manage 2011;37: 1464-79.

Hetemäki L. ICT and communication paper markets. In: Hetemäki L, Nilsson S, editors. Information technology and the forest sector IUFRO World Series, Vol. 18. Vienna: IUFRO; 2005. p. 76-104.

Huhtala A, Samakovlis E. Does international harmonization of environmental policy instruments make economic sense? Environ Resour Econ 2002;21:261-286.

Klineberg SL, M cKeever M, Rothenbach B. Demographic predictors of environmental concern: It does make a difference how it's measured. Soc Sci Quart 1998;79:734-753.

Laurijssen J, M arsidi M, Westenbroek A, Worrell E, Faaij A. Paper and biomass for energy? The impact of paper recycling on energy and $\mathrm{CO}_{2}$ emissions. Resour Conserv Recy 2010;54:1208-18.

Lundmark R. Choice of location for investments in the European paper industry: The impact of wastepaper. Resour Conserv Recy 2001;33:167-180.

M arquart-Pyatt ST. Are there similar sources of environmental concern? Comparing industrialized countries. Soc Sci Quart 2008;89:1312-35.

M iranda R, Blanco A. Environmental awareness and paper recycling. Cell Chem Technol 2010;44:431-449.

M iranda R, Bobu E, Grossmann H, Stawicki B, Blanco A. Factors influencing a higher use of recovered paper in the European paper industry. Cell Chem Technol 2010;44:419-30.

Prahalad CK, Hammond A. Serving the world's poor, profitably. Harvard Bus Rev 2002;80: 48-57. 
RISI. Industry statistics database 2012.

Samakovlis E. The relationship between waste paper and other inputs in the Swedish paper industry. Environ Resour Econ 2003;25:191-212.

van Beukering PJH, Bouman M N. Empirical evidence on recycling and trade of paper and lead in developed and developing countries. World Dev 2001;29:1717-37.

van Beukering PJH, van den Bergh JCJM. M odelling and analysis of international recycling between developed and developing countries. Resour Conserv Recy 2006;46,1-26.

World Bank. How we Classify Countries [cited 2013 Jun 4]. Available from:

http://data.worldbank.org/about/country-classifications

World Bank. World Development Indicators database 2012 [cited 2012 Nov 15]. Available from: http://databank.worldbank.org/data/databases.aspx 


\section{Appendix}

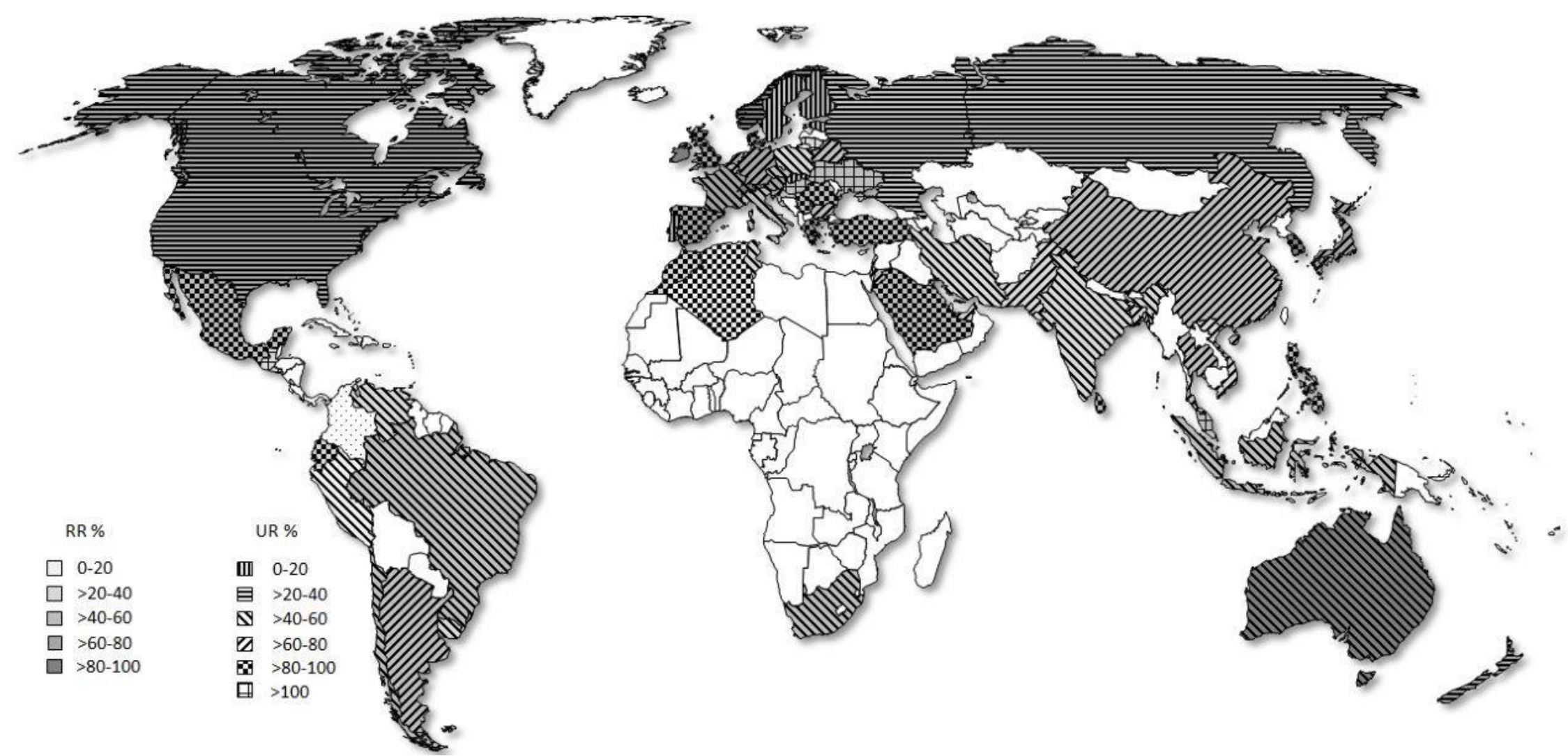

Figure A.1 Recovery and utilization rates of 70 countries in 2010 
Table A.1 An overview of previous empirical studies

\begin{tabular}{|c|c|c|c|c|c|c|c|}
\hline Econometric studies & data & years & $\begin{array}{c}\text { n of } \\
\text { countries }\end{array}$ & estimation method & $\begin{array}{l}\text { dependent } \\
\text { variable(s) }\end{array}$ & income groups & $\begin{array}{c}\text { proxy for } \\
\text { environmental } \\
\text { awareness }\end{array}$ \\
\hline van Beukering and Bouman (2001) & pooled panel & 1970-1997 & 50 & GLS & $\mathrm{RR}, \mathrm{UR}$ & $\begin{array}{c}\text { developed and } \\
\text { developing } \\
\text { countries }\end{array}$ & $\begin{array}{l}\text { wage in } \\
\text { manufacturing } \\
\text { sector }\end{array}$ \\
\hline $\begin{array}{l}\text { Berglund, Söderholm and Nilsson } \\
\text { (2002) }\end{array}$ & cross-section & 1995 & $\begin{array}{l}89 \text { (RR), } \\
81 \text { (UR) }\end{array}$ & OLS (RR), 2SLS (UR) & $\mathrm{RR}, \mathrm{UR}$ & - & GDP per capita \\
\hline Berglund and Söderholm (2003a) & pooled panel & $1990-1996$ & $\begin{array}{l}39 \text { (RR), } \\
49 \text { (UR) }\end{array}$ & OLS (RR), 2SLS (UR) & $\mathrm{RR}, \mathrm{UR}$ & $\begin{array}{l}\text { high income } \\
\text { and middle } \\
\text { income } \\
\text { high income }\end{array}$ & GDP per capita \\
\hline Berglund and Söderholm (2003b) & pooled panel & 1990-1996 & 49 & 2SLS (UR) & UR & $\begin{array}{l}\text { and middle } \\
\text { income }\end{array}$ & - \\
\hline Other studies & data & $\begin{array}{l}\mathrm{n} \text { of } \\
\text { respondents }\end{array}$ & $\begin{array}{l}\text { countries } \\
\text { included }\end{array}$ & objective & methods & $\begin{array}{c}\text { proxy for } \\
\text { environmental } \\
\text { awareness } \\
\end{array}$ & \\
\hline M iranda and Blanco (2010) & $\begin{array}{c}\text { expert } \\
\text { questionnaire } \\
\text { +secondary }\end{array}$ & 21 & $\begin{array}{c}31 \\
\text { European } \\
\text { countries }\end{array}$ & $\begin{array}{l}\text { to present (1) the } \\
\text { most important } \\
\text { driving forces for } \\
\text { the collection of } \\
\text { recycled paper, and } \\
\text { (2) the available } \\
\text { tools for increasing } \\
\text { citizens' } \\
\text { environmental } \\
\text { awareness }\end{array}$ & $\begin{array}{l}\text { correlations, } \\
\text { descriptive }\end{array}$ & $\begin{array}{c}\text { average value } \\
\text { of the rates } \\
\text { given }\end{array}$ & \\
\hline M iranda et al. (2010) & $\begin{array}{c}\text { expert } \\
\text { questionnaire }\end{array}$ & 19 & $\begin{array}{c}19 \\
\text { European } \\
\text { countries }\end{array}$ & $\begin{array}{l}\text { to overview the } \\
\text { paper and board } \\
\text { recycling sector in } \\
\text { Europe and the } \\
\text { factors that might } \\
\text { possibly limit the } \\
\text { use of recycled } \\
\text { paper }\end{array}$ & descriptive & - & \\
\hline
\end{tabular}


Table A.2 Correlation matrix

1.

2.

3.

4.

5.

6.

7.

8.

9.

10.

11.

\begin{tabular}{|c|c|c|c|c|c|c|c|c|c|c|c|}
\hline 1. Recovery rate (RR) & 1 & & & & & & & & & & \\
\hline 2. Utilization rate (UR) & -0.0725 & 1 & & & & & & & & & \\
\hline 3. GDP per capita & 0.6307 & -0.1843 & 1 & & & & & & & & \\
\hline 4. Urbanization & 0.3015 & -0.0789 & 0.4938 & 1 & & & & & & & \\
\hline 5. Population density & 0.1204 & 0.1982 & 0.0296 & -0.2969 & 1 & & & & & & \\
\hline 6. Schooling & 0.5254 & -0.2374 & 0.5356 & 0.4688 & -0.0966 & 1 & & & & & \\
\hline 7. Forest area & -0.0271 & -0.2904 & -0.0180 & 0.1161 & -0.2026 & 0.0886 & 1 & & & & \\
\hline 8. Paper product mix & -0.3530 & 0.4247 & -0.3189 & 0.0666 & -0.1782 & -0.0455 & -0.0258 & 1 & & & \\
\hline 9. Structural effect & 0.2746 & -0.5790 & 0.3296 & 0.0304 & -0.1568 & 0.2066 & 0.0894 & -0.4371 & 1 & & \\
\hline 10. ISO14001 certificates & 0.4881 & -0.1424 & 0.4419 & 0.1771 & 0.0035 & 0.3568 & -0.0940 & -0.2162 & 0.3849 & 1 & \\
\hline 11. Paper consumption & 0.1843 & -0.0993 & 0.3085 & 0.0239 & 0.0333 & 0.2116 & 0.3399 & -0.1618 & 0.0012 & -0.0113 & 1 \\
\hline
\end{tabular}


Table A.3 Countries included in the econometric analysis

\begin{tabular}{|c|c|c|c|c|c|}
\hline $\begin{array}{l}\text { All countries } \\
(\mathrm{N}=70)\end{array}$ & & & $\begin{array}{l}\text { High-income countries } \\
(\mathrm{N}=33)\end{array}$ & & $\begin{array}{l}\text { Lower-middle and low- } \\
\text { income countries } \\
(\mathrm{N}=12)\end{array}$ \\
\hline Algeria & Guatemala & Romania & Australia & Slovakia & Bangladesh \\
\hline Argentina & Hungary & Russia & Austria & Slovenia & Egypt \\
\hline Australia & India & Saudi Arabia & Belgium & South Korea & El Salvador \\
\hline Austria & Indonesia & Serbia & Canada & Spain & Guatemala \\
\hline Bangladesh & Iran & Slovakia & Croatia & Sweden & India \\
\hline Belarus ${ }^{a}$ & Ireland & Slovenia & Czech Republic & Switzerland & Indonesia \\
\hline Belgium & Israel & South Africa & Denmark & United Arab Emirates & Morocco \\
\hline Brazil & Italy & South Korea & Estonia & United Kingdom & Pakistan \\
\hline Bulgaria & Japan & Spain & Finland & United States & Philippines \\
\hline Canada & Jordan & Sri Lanka & France & & Sri Lanka \\
\hline Chile & Kuwait & Sweden & Germany & & Ukraine \\
\hline China & Lebanon $^{\mathrm{a}}$ & Switzerland & Greece & & Vietnam \\
\hline Colombia & Lithuania & Thailand & Hungary & & \\
\hline Croatia & Malaysia & Tunisia & Ireland & & \\
\hline Czech Republic & Mexico & Turkey & Israel & & \\
\hline Denmark & Morocco & Ukraine & Italy & & \\
\hline Ecuador & Netherlands & United Arab Emirates & Japan & & \\
\hline Egypt & New Zealand & United Kingdom & Kuwait & & \\
\hline El Salvador & Norway & United States & Netherlands & & \\
\hline Estonia & Pakistan & Uruguay & New Zealand & & \\
\hline Finland & Peru & Venezuela & Norway & & \\
\hline France & Philippines & Vietnam & Poland & & \\
\hline Germany & Poland & & Portugal & & \\
\hline Greece & Portugal & & Saudi Arabia & & \\
\hline
\end{tabular}

aBelarus and Lebanon are not included in the RR estimations with schooling as an explanatory variable. 